\title{
THE EXISTENCE OF A UNIQUE SOLUTION TO A MIXED CONTROL PROBLEM FOR SOBOLEV-TYPE EQUATIONS
}

\author{
A.V. Keller, South Ural State University, Chelyabinsk, Russian Federation, \\ alevtinak@inbox.ru,
}

$\boldsymbol{A} . \boldsymbol{A}$. Ebel, South Ural State University, Chelyabinsk, Russian Federation, ebel@mail.ru

\begin{abstract}
This article studies a mixed control problem for Sobolev-type equations in the case of a relatively radial operator. We use the Showalter-Sidorov initial condition. The difference in the statement of our problem from those studied previously by other researchers amounts to the form of the quality functional, which, in the authors' opinion, is more adequate to model applications in economics and technology. We prove an existence and uniqueness theorem for the solution to this problem.

Keywords: mixed control problem; optimal control; Sobolev-type system; ShowalterSidorov condition.
\end{abstract}

Sviridyuk and Efremov posed and studied [1, 2] an optimal control problem for Sobolev-type equations for the first time, proving the existence of a unique solution to this problem with the Cauchy initial condition in the cases of relative boundedness and relative sectoriality of the operator. It is proved in [3] that there exists a unique solution to the Showalter-Sidorov problem for Sobolev-type equations with strongly $(L, p)$-radial operator. Fedorov and Plekhanova continued [4] the study of various optimal control problems for linear Sobolev-type equations. The approach in these articles is similar to [5]. Manakova studied [6] sufficient conditions for the solvability of the Showalter-Sidorov optimal control problem for certain semilinear Sobolev-type equations. The goal of this article is to prove the existence of a unique solution to the Showalter-Sidorov mixed optimal control problem for Sobolev-type equations with strongly $(L, p)$-radial operator.

Consider the Sobolev-type equation

$$
L \dot{x}(t)=M x(t)+B u(t)+y(t),
$$

assume that the functions $x(t), y(t)$, and $u(t)$ lie in some Hilbert spaces $\mathfrak{X}, \mathfrak{Y}$, and $\mathfrak{U}$ respectively. Consider two operators $M$ and $L$; more exaclty, $L \in \mathcal{L}(\mathfrak{X}, \mathfrak{Y})$, where $\mathcal{L}(\mathfrak{X}, \mathfrak{Y})$ is the set of continuous linear operators acting from $\mathfrak{X}$ to $\mathfrak{Y}$, and ker $L \neq\{0\}$, while $M \in C l(\mathfrak{X} ; \mathfrak{Y})$ (that is, a closed operator $M: \operatorname{dom} M \rightarrow \mathfrak{Y}$ whose domain $\operatorname{dom} M$ is dense in $\mathfrak{X}$. Consider also $B \in \mathcal{L}(\mathfrak{U} ; \mathfrak{Y})$. Assume in addition that the operator $M$ is strongly $(L, p)$-radial [5, ch. 2].

Introduce in considering three spaces,

the states $H^{1}(\mathfrak{X})=\left\{x \in L_{2}((0 ; \tau) ; \mathfrak{X}): \dot{x} \in L_{2}((0 ; \tau) ; \mathfrak{X})\right\}$;

and the controls $\left.\mathfrak{U}=H^{p+1}(\mathfrak{U})=\left\{u \in L_{2}((0 ; \tau) ; \mathfrak{U}): \dot{u}^{(} p+1\right) \in L_{2}((0 ; \tau) ; \mathfrak{U})\right\}$ and $\mathfrak{U}^{0}$ is space $\mathfrak{X}$ or subspace is it equipped with another norm.

Distinguish in $\mathfrak{U}^{0}$ a compact convex set $\mathfrak{U}_{a d}^{0}$ of initial admissible controls, as well as a compact convex set $\mathfrak{U}_{a d}$ in $\mathfrak{U}$.

Denote by $\mathfrak{Z}$ the Hilbert space of observations Each selfadjoint operator $C \in \mathcal{L}(\mathfrak{X}, \mathfrak{Z})$ determines the observation $z(t)=C x(t)$. If $x \in H^{1}(\mathfrak{X})$ then $z \in H^{1}(\mathfrak{Z})$. Define positive definite selfadjoint operators $N_{\theta} \in \mathcal{L}(\mathfrak{U})$ for $\theta=0,1, \ldots, p+1$. 
Consider the mixed optimal control problem for (1) with the Showalter-Sidorov initial condition

$$
\left[R_{\mu}^{L}(M)\right]^{p+1}\left(x(0)-u_{0}\right)=0,
$$

where $R_{\mu}^{L}(M)=(\mu L-M)^{-1} L$ is the right $L$-resolution of $M$. Furthermore,

$$
J\left(v(t), v_{0}\right)=\min _{\left(u_{0}, u\right) \in \mathfrak{U}_{a d}^{0} \times \mathfrak{U}_{a d}} J\left(u(t), u_{0}\right),
$$

where

$$
\begin{gathered}
J\left(u(t), u_{0}\right)=\alpha \sum_{q=0}^{1} \int_{0}^{t}\left\|C x^{(q)}\left(t, u_{0}, u(t)\right)-C x_{0}^{(q)}(t)\right\|_{H^{1}(\mathfrak{X})} d t+ \\
+\beta \sum_{q=0}^{\theta} \int_{0}^{\tau}\left\langle N_{q} u^{(q)}(t), u^{(q)}(t)\right\rangle_{\mathfrak{U}} d t+\gamma\left\|u_{0}\right\|_{\mathfrak{U}^{0}}^{2}
\end{gathered}
$$

where $\alpha+\beta+\gamma=1, \theta=0,1, \ldots, p+1, p \in\{0\} \cup \mathbb{N}, t \in(0 ; \tau), \tau \in \mathbb{R}_{+}=\{\tau \in \mathbb{R}, \tau>0\}$.

Note that Islamova [7] studied the existence of a unique solution of mixed optimal control problem for Sobolev type equations with functional in different form

$$
J\left(x, u_{0}, u(t)\right)=\frac{1}{2}\|x-\tilde{x}\|_{H^{r_{1}(\mathfrak{X})}}^{2}+\frac{N_{1}}{2}\|u-\tilde{u}\|_{H^{r_{2}(\mathfrak{U})}}^{2}+\frac{N_{2}}{2}\left\|u_{0}-\tilde{u}_{0}\right\|_{\mathfrak{X}}^{2} \rightarrow \inf ,
$$

where $\tilde{u}, \tilde{u}_{0}$ and $\tilde{u}$ are given.

Interpretation of such functional, for example in economic models, raises questions about the adequacy of the model based on it. The subject is to find such mixed optimal control for which the goal is to achieve the planned system states and the planned start and current controls, while the weights indicate the equivalence of criteria to achieve the planned states and the planned control. Thus by finding such "compromise optimal control" we get one of two situations: 1) the found control, being close to the given one, is not optimal for achieving of the planned parameters; 2) the assumption that the given controls are some sort of Etalon, make the problem of finding of optimal control irrelevant. Thus, in our view, the criterion for the effectiveness of control in economic systems is not obvious. As for technical systems such compromise situations are hardly acceptable as well, since the receive of inaccurate system states and external influence, which is the control, is meaningless. However, recognizing the value of mathematical result obtained in [7], we can assume that, the functional of this type can be useful in some applications.

In this paper, the quality functional has a definite economic meaning in achieving of the planned parameters at the lowest control and various weights for control criteria. It continues to develop investigations [8].

Put

$$
\begin{gathered}
\rho^{L}(M)=\left\{\mu \in \mathbb{C}:(\mu L-M)^{-1} \in \mathcal{L}(\mathfrak{F} ; \mathfrak{U})\right\}, \sigma^{L}(M)=\mathbb{C} \backslash \rho^{L}(M), \\
R_{\mu}^{L}(M)=(\mu L-M)^{-1} L, L_{\mu}^{L}(M)=L(\mu L-M)^{-1}, \mu \in \rho^{L}(M), \\
R_{(\lambda, p)}^{L}(M)=\prod_{k=0}^{p} R_{\lambda_{k}}^{L}(M), L_{(\lambda, p)}^{L}(M)=\prod_{k=0}^{p} L_{\lambda_{k}}^{L}(M), \lambda_{k} \in \rho^{L}(M) .
\end{gathered}
$$

Definition 1. An operator $M$ is called p-radial with respect to $L$ (or (L,p)-radial) whenever 
(i) $\exists \omega \in \mathbb{R} \forall \mu>\omega \Rightarrow \mu \in \rho^{L}(M)$;

(ii) $\exists K>0 \forall \mu_{k}>\omega, k=\overline{0, p}, \forall n \in \mathbb{N}$

$$
\max \left\{\left\|\left(R_{(\mu, p)}^{L}(M)\right)^{n}\right\|_{\mathcal{L}(\mathfrak{X})},\left\|\left(L_{(\mu, p)}^{L}(M)\right)^{n}\right\|_{\mathcal{L}(\mathfrak{X})}\right\} \leq \frac{K}{\prod_{k=0}^{p}\left(\mu_{k}-\omega\right)^{n}} .
$$

In addition, put

$$
\begin{aligned}
& \mathfrak{X}^{0}=\operatorname{ker} R_{(\mu, p)}^{L}(M), \mathfrak{Y}^{0}=\operatorname{ker} L_{(\mu, p)}^{L}(M), L_{0}=\left.L\right|_{\mathfrak{X}^{0}}, M_{0}=\left.M\right|_{d o m M \cap \mathfrak{X}^{0}}, \\
& \mathfrak{X}^{1}=\overline{i m R_{(\mu, p)}^{L}(M)}, \mathfrak{Y}^{1}=\overline{i m L_{(\mu, p)}^{L}(M)}, \tilde{\mathfrak{X}}=\mathfrak{X}^{0} \dot{+i m R_{(\mu, p)}^{L}(M)}, \tilde{\mathfrak{Y}}=\mathfrak{Y}^{0} \dot{+} \overline{i m L_{(\mu, p)}^{L}(M)}
\end{aligned}
$$

Definition 2. A strongly continuous mapping $V^{\bullet}: \mathbb{R}_{+} \rightarrow \mathcal{L}(\mathcal{V})$ is called a strongly continuous semigroup of resolving operators whenever

(i) $V^{s} V^{t}=V^{s+t}$ for all $s, t>0$;

(ii) $v(t)=V^{t} v_{0}$ is a solution for every $v_{0}$ in a dense linear subspace of $\mathcal{V}$.

(iii) $\exists \lim _{t \rightarrow 0+} V^{t}$ for every $v \in \mathcal{V}$.

Theorem 1. [5] Given an $(L, p)$-radial operator $M$, there exists a strongly continuous resolving semigroup for the equation (1) considered on the subspace $\tilde{\mathfrak{X}}$.

Remark 1. We can express the operators in the resolvent semigroup for (1) with $t>0$ as

$$
X(t)=s-\lim _{k \rightarrow \infty}\left(\left(L-\frac{t}{k} M\right)^{-1} L\right)^{k}=s-\lim _{k \rightarrow \infty}\left(\frac{t}{k} R_{k / t}^{L}(M)\right)^{k} .
$$

Definition 3. An operator $M$ is called strongly $(L, p)$-radial whenever the following conditions are fulfilled for arbitrary $\lambda, \mu_{0}, \mu_{1}, \ldots, \mu_{p}>\omega$ :

(i) there exists a dense linear subspace $\stackrel{\circ}{Y}$ of $\mathfrak{Y}$ such that

$$
\left\|M(\lambda L-M)^{-1} L_{(\mu, p)}^{L}(M) y\right\|_{\mathfrak{Y}} \leq \frac{\operatorname{const}(y)}{(\lambda-\omega) \prod_{k=0}^{p}\left(\mu_{k}-\omega\right)}
$$

for all $y \in \stackrel{\circ}{\mathfrak{Y}}$;

(ii) we have

$$
\left\|R_{(\mu, p)}^{L}(M)(\lambda L-M)^{-1}\right\|_{\mathcal{L}(\mathfrak{Y} ; \mathfrak{X})} \leq \frac{K}{(\lambda-\omega) \prod_{k=0}^{p}\left(\mu_{k}-\omega\right)} .
$$

Theorem 2. Given a strongly $(L, p)$-radial operator $M$, the following claims hold:

(i) $\mathfrak{X}=\mathfrak{X}^{0} \oplus \mathfrak{X}^{1}$ and $\mathfrak{Y}=\mathfrak{Y}^{0} \oplus \mathfrak{Y}^{1}$;

(ii) $L_{k}=\left.L\right|_{\mathfrak{X}^{k}} \in \mathcal{L}\left(\mathfrak{X}^{k} ; \mathfrak{Y}^{k}\right)$ and $M_{k}=\left.M\right|_{\operatorname{dom}_{k}} \in C l\left(\mathfrak{X}^{k} ; \mathfrak{Y}^{k}\right)$, dom $M_{k}=\operatorname{dom} M \cap \mathfrak{X}^{k}$ for $k=0,1$;

(iii) the inverse operators $M_{0}^{-1} \in \mathcal{L}\left(\mathfrak{Y}^{0} ; \mathfrak{X}^{0}\right)$ and $L_{1}^{-1} \in \mathcal{L}\left(\mathfrak{Y}^{1} ; \mathfrak{X}^{1}\right)$ exist.

Definition 4. Call a triple $\left(v(t), v_{0}, x\left(v_{0}, v(t)\right)\right) \in \mathfrak{U}_{a d} \times \mathfrak{U}_{a d}^{0} \times \mathfrak{X}$ a solution to the mixed optimal control problem (1)-(4) whenever

$$
J\left(v(t), v_{0}\right)=\min _{\left(u_{0}, u\right) \in \mathfrak{U}_{a d}^{0} \times \mathfrak{U}_{a d}} J\left(u(t), u_{0}\right),
$$


where $\left(v(t), v_{0}, x\left(v_{0}, v(t)\right)\right) \in \mathfrak{U}_{a d} \times \mathfrak{U}_{a d}^{0} \times X$ satisfy (1) and (2).

Let us verify the existence of a unique solution $\left(v(t), v_{0}, x\left(v_{0}, v(t)\right)\right) \in \mathfrak{U}_{a d} \times \mathfrak{U}_{a d}^{0} \times \mathfrak{X}$ for $(1)-(4)$. Consider the inner product in the space $H^{p+1}(\mathfrak{Y})$ :

$$
[w, u]=\sum_{q=1}^{\theta} \int_{0}^{\tau}\left\langle w^{(q)}, u^{(q)}\right\rangle_{\mathfrak{U}} d t
$$

where $w^{(q)}=N_{q} u^{(q)}$.

Theorem 3. Given a strongly $(L, p)$-radial operator $M$ with $p \in 0 \cup \mathbb{N}$, for every $y \in$ $H^{p+1}(\mathfrak{Y})$ there exists a unique strong solution $\left(v(t), v_{0}, x\left(v_{0}, v(t)\right)\right) \in \mathfrak{U}_{a d} \times \mathfrak{U}_{a d}^{0} \times \mathfrak{X}$ to the mixed optimal control problem (1)-(4). Furthermore,

$$
\begin{gathered}
x\left(v(t), v_{0}\right)=X^{t} P v_{0}+\int_{0}^{t} X^{t-s} L_{1}^{-1} Q(y(s)+B v(s)) d s- \\
-\sum_{k=0}^{p}\left(M_{0}^{-1} L_{0}\right)^{k} M_{0}^{-1}(I-Q)(y(t)+B v(t))^{(k)} .
\end{gathered}
$$

Proof. Fix $y \in H^{p+1}(\mathfrak{Y})$ and consider (5) as a continuous mapping

$$
D:\left(u(t), u_{0}\right) \rightarrow x\left(t, u(t), u_{0}\right) .
$$

Using (6), write down the quality functional (3):

$$
J\left(u, u_{0}\right)=\left\|C x\left(t, u, u_{0}\right)-z_{0}\right\|_{H^{1}(\mathfrak{Z})}^{2}+[w, u]+\left\|u_{0}\right\|_{H^{1}(\mathfrak{Z})}^{2},
$$

where

$$
\begin{gathered}
\left\|C x\left(t, u, u_{0}\right)-z_{0}\right\|_{H^{1}(\mathfrak{Z})}^{2}= \\
=\left\|C x\left(t, u, u_{0}\right)-C x\left(t, 0, u_{0}\right)+C x\left(t, 0, u_{0}\right)-C x(t, 0,0)+C x(t, 0,0)-z_{0}\right\|_{H^{1}(\mathfrak{Z})}^{2} \leqslant \\
\leqslant\left\|C x\left(t, u, u_{0}\right)-C x\left(t, 0, u_{0}\right)\right\|_{H^{1}(\mathfrak{Z})}^{2}+\left\|C x\left(t, 0, u_{0}\right)-C x(t, 0,0)\right\|_{H^{1}(\mathfrak{Z})}^{2}+ \\
+\left\|C x(t, 0,0)-z_{0}\right\|_{H^{1}(\mathfrak{Z})}^{2}+ \\
+2\left\langle C x\left(t, u, u_{0}\right)-C x\left(t, 0, u_{0}\right), C x\left(t, 0, u_{0}\right)-C x(t, 0,0)\right\rangle_{H^{1}(\mathfrak{Z})}+ \\
+2\left\langle C x\left(t, u, u_{0}\right)-C x\left(t, 0, u_{0}\right), C x(t, 0,0)-z_{0}\right\rangle_{H^{1}(\mathfrak{Z})} \\
+2\left\langle C x\left(t, 0, u_{0}\right)-C x(t, 0,0), C x(t, 0,0)-z_{0}\right\rangle_{H^{1}(\mathfrak{Z})}, \\
z_{0}=C x(0,0,0) .
\end{gathered}
$$

Introducing on $H^{p+1}(\mathfrak{U})$ the continuous coercive bilinear form

$$
\begin{gathered}
\pi\left(\left(u ; u_{0}\right),\left(u ; u_{0}\right)\right)= \\
=\left\|C x\left(t, u, u_{0}\right)-C x\left(t, 0, u_{0}\right)\right\|_{H^{1}(\mathfrak{Z})}^{2}+\left\|C x\left(t, 0, u_{0}\right)-C x(t, 0,0)\right\|_{H^{1}(\mathfrak{Z})}^{2}+ \\
+2\left\langle C x\left(t, u, u_{0}\right)-C x\left(t, 0, u_{0}\right), C x\left(t, 0, u_{0}\right)-C x(t, 0,0)\right\rangle_{H^{1}(\mathfrak{Z})}+
\end{gathered}
$$




$$
+[w, u]+\left\|u_{0}\right\|^{2}
$$

and the continuous linear forms

$$
\begin{aligned}
& \lambda(u)=\left\langle z_{0}-C x(t, 0,0), C x\left(t, u, u_{0}\right)-C x\left(t, 0, u_{0}\right)\right\rangle_{H^{1}(\mathfrak{Z})}, \\
& \lambda\left(u_{0}\right)=\left\langle z_{0}-C x(t, 0,0), C x\left(t, 0, u_{0}\right)-C x(t, 0,0)\right\rangle_{H^{1}(\mathfrak{Z})},
\end{aligned}
$$

we obtain the functional

$$
J\left(u_{0}, u(t)\right)=\pi\left(\left(u ; u_{0}\right),\left(u ; u_{0}\right)\right)-2 \lambda(u)-2 \lambda\left(u_{0}\right)+\left\|z_{0}-C x(t, 0,0)\right\|_{H^{1}(\mathfrak{Z})}^{2} .
$$

Hence, the hypotheses of the theorem in the first chapter of [9] hold.

The proof of the theorem is complete.

\section{References}

1. Sviridyuk G.A., Efremov A.A. Optimal Control of Sobolev-Type Linear Equations with Relatively p-Sectorial Operators. Differential Equations, 1995, vol. 31, no. 11, pp. $1882-1890$.

2. Sviridyuk G.A., Efremov A.A. Optimal Control Problem for One Class of Linear Sobolev Type Equations. Russian Mathematics (Izvestiya VUZ. Matematika), 1996, vol. 40, no. 12 , pp. $60-71$.

3. Zagrebina S.A., Sagadeeva M.A. The Generalized Showalter - Sidorov Problem for the Sobolev type Equations with strongly $(L, p)$-radial operator. Vestnik Magnitogorskogo gosudarstvennogo universiteta. Seria «Matematika» [Bulletin of Magnitogorsk State University. Series «Mathematics»], 2006, issue 9, pp. 17-27. (in Russian)

4. Fedorov V.E., Plehanova M.V. Optimal Control of Sobolev Type Linear Equations. Differential Equations, 2004, vol. 40, no. 11, pp. 1627-1637. DOI: $10.1007 / \mathrm{s} 10625-005-0082-9$

5. Sviridyuk, G.A., Fedorov V.E. Linear Sobolev Type Equations and Degenerate Semigroups of Operators. Utrecht, Boston, Köln, VSP, 2003. 179 p. DOI: $10.1515 / 9783110915501$

6. Manakova N.A., Bogonos E.A. Optimal Control to Solutions of the Showalter-Sidorov Problem for a Sobolev Type Equation. The Bulletin of Irkutsk State University. Series: Mathematics, 2010, vol. 3, no. 1, pp. 42-53. (in Russian)

7. Islamova A.F. Zadachi smeshannogo upravleniya dlya lineynykh raspredelennykh sistem sobolevskogo tipa [Mixed Optimal Control Problem for Linear Distributed Sobolev Type Systems. The Dissertation for Scientific Degree of the Candidate of Physical and Mathematical Sciences]. Chelyabinsk, Chelyabinsk State University, 2012. 129 p.

8. Keller A.V. Chislennoe issledovanie zadach optimal'nogo upravleniya dlya modeley leont'evskogo tipa [Numerical Reseach of Optimal Control Problem for Leontieff Type Models. The Dissertation for Scientific Degree of the Doctor of Physical and Mathematical Sciences]. Chelyabinsk, South Ural State University, 2011. 252 p. 
9. Lions J.-L. Contrôle optimal de systémes gouvernés par des équations aux dérivées partielles. Dunod, Paris, 1968.

\title{
СУЩЕСТВОВАНИЕ ЕДИНСТВЕННОГО РЕШЕНИЯ ОДНОЙ ЗАДАЧИ СМЕШАННОГО УПРАВЛЕНИЯ ДЛЯ УРАВНЕНИЙ СОБОЛЕВСКОГО ТИПА
}

\author{
А.В. Келлер, А.А. Эбель
}

\begin{abstract}
В работе рассмотрена задача смешанного управления для уравнений соболевского типа в случае относительно радиального оператора. В качестве начального используется условие Шоуолтера-Сидорова. Отличием постановки задачи от ранее изученных другими исследователями заключается в виде функционала качества, который, по мнению авторов, является более адекватным моделируемым экономическим и техническим задачам. Доказана теорема о существовании единственного решения указанной задачи.

Ключевые слова: задача смечанного управления; оптимальное управление; система соболевского типа; условие Шоултера-Сидорова.
\end{abstract}

\section{Литература}

1. Свиридюк, Г.А. Оптимальное управление линейными уравнениями типа Соболева с относительно p-секториальными операторами / Г.А. Свиридюк, А.А. Ефремов // Дифференциальные уравнения. - 1995. - Т. 31. - С. 1912-1919.

2. Свиридюк, Г.А. Задача оптимального управления для одного класса линейных уравнений типа Соболева / Г.А. Свиридюк, А.А. Ефремов // Известия вузов. Математика. - 1996. - Т. 40, № 12. - С. 75-83.

3. Сагадеева, М.А. Задачи оптимального и жесткого управления решениями специального вида нестационарных уравнений соболевского типа / М.А. Сагадеева, А.Н. Шулепов // Вестник СамГТУ. Серия: Физико-математические науки. 2014. - № 2 (35). - C. 156-160.

4. Федоров, В.Е. Оптимальное управление линейными уравнениями соболевского типа / В.Е. Федоров, М.В. Плеханова // Дифференц. уравнения. - 2004. - Т. 40, № 11. - С. $1548-1556$.

5. Sviridyuk, G.A., Fedorov V.E. Linear Sobolev Type Equations and Degenerate Semigroups of Operators / G.A. Sviridyuk, V.E. Fedorov. - Utrecht; Boston: VSP, 2003. - 179 p.

6. Манакова, Н.А. Оптимальное управление решениями задачи ШоуолтераСидорова для одного уравнения соболевского типа / Н.А. Манакова, Е.А. Богонос // Известия Иркутского государственного университета. Серия: Математика. 2010. - Т. 3, № 1. - С. 42-53.

7. Исламова, А.Ф. Задачи смешанного управления для линейных распределенных систем соболевского типа: дис. ... канд. физ.-мат. наук / А.Ф. Исламова. - Челябинск, ЧелГУ, 2012. - С. 37-47. 
8. Келлер, А.В. Численное исследование задач оптимального управления для моделей леонтьевского типа: дис. ... д-ра физ.-мат. наук / А.В. Келлер. - Челябинск, ЮУрГУ, 2011. - 252 с.

9. Лионс, Ж.-Л. Управление сингулярными распределенными системами. - М.: Мир, 1972. - 587 с.

Алевтина Викторовна Келлер, доктор физико-математических наук, доцент, кафедра «Математическое моделирование», Южно-Уральский государственный университет (г. Челябинск, Российская Федерация), alevtinak@inbox.ru.

Андрей Александрович Эбель, аспирант, кафедра «Математическое моделирование», Южно-Уральский государственный университет (г. Челябинск, Российская Федерация), ebel@mail.ru.

Поступила в редакчию 2 июня 2014 г. 